\title{
Pemindahan Fungsi Yuqi Zhuci Tipikal dalam Terjemahan Bahasa Cina-Bahasa Melayu
}

\section{Transference of Functions of Typical Yuqi Zhuci in Chinese-Malay Translation}

\author{
JENNICA CHIN AI AI \\ *GOH SANG SEONG \\ Translation Studies and Interpreting Section, School of Humanities, Universiti Sains Malaysia, \\ 11800 USM Pulau Pinang, Malaysia \\ *Corresponding author: gohss@usm.my
}

Published online: 15 May 2019

To cite this article: Chin, A.A. and Goh, S.S. 2019. Pemindahan fungsi yuqi zhuci tipikal dalam terjemahan bahasa Cina-bahasa Melayu. KEMANUSIAAN the Asian Journal of Humanities 26(1): 89-112, https://doi.org/10.21315/kajh2019.26.1.4

To link to this article: https://doi.org/10.21315/kajh2019.26.1.4

\begin{abstract}
Abstrak. Kata abstrak "yuqi zhuci tipikal” yang lazimnya digunakan pada penghujung ujaran bahasa Cina mendukung pelbagai fungsi tatabahasa dalam bahasa Cina. Penggunaan kata abstrak seumpama ini tidak berlaku dalam bahasa Melayu. Makalah ini bertujuan mengenal pasti fungsi setiap yuqi zhuci tipikal dalam bahasa Cina seterusnya meneliti ketersampaian fungsi tersebut dalam terjemahan teks bahasa Melayu. Untuk tujuan analisis, kajian ini memanfaatkan definisi yuqi zhuci oleh Zhang Bin (2010), pengkategorian yuqi zhuci oleh Shao Jingmin (2007) dan fungsi yuqi zhuci tipikal berdasarkan jenis ayat bahasa Cina oleh Zhang Bin (2010). Sebanyak 527 ayat yang mengandungi item yuqi zhuci tipikal berjaya dikutip secara manual. Item yuqi zhuci tipikal ini dikategorikan mengikut jenis ayat kehadirannya, iaitu ayat pertanyaan ( 29.6 peratus), ayat imperatif (4.6 peratus), ayat kepastian (62.6 peratus), ayat interjektif ( 2.7 peratus) dan ayat elipsis (0.5 peratus). Bagi mengelakkan pengulangan analisis data yang serupa polanya, hanya 35 item yuqi zhuci tipikal diambil sebagai data kajian berdasarkan fungsi item tersebut yang tidak berulang dalam ayat kehadiran yang berbeza. Data dianalisis secara deskriptif dan berdasarkan konteks ayat. Dapatan kajian menunjukkan bahawa fungsi bagi keenam-enam jenis yuqi zhuci tipikal bersifat khusus berdasarkan cara penggunaannya dalam pelbagai jenis ayat bahasa Cina. Kajian juga mendapati bahawa fungsi yuqi zhuci tipikal upaya disampaikan kembali daripada teks sumber kepada teks bahasa Melayu melalui konteks ayat, manakala yuqi zhuci tipikal yang tidak upaya diungkapkan kembali ke dalam teks sasaran adalah kerana perbezaan emik antara bahasa sumber dengan bahasa sasaran serta isu salah terjemah. Secara tuntasnya, pemindahan fungsi yuqi zhuci tipikal daripada teks bahasa Cina kepada teks bahasa Melayu banyak bergantung pada faktor pengenalpastian fungsi
\end{abstract}


yuqi zhuci tipikal yang hadir dalam teks sumber, konteks cerita, niat penutur dan ketepatan nada penutur. Jelas bahawa ketersampaian fungsi yuqi zhuci tipikal tidak bergantung pada padanan leksikal dalam teks sasaran.

Kata kunci dan frasa: yuqi zhuci tipikal, kata abstrak, fungsi tatabahasa, pemindahan, terjemahan bahasa Cina-bahasa Melayu

\begin{abstract}
Abstract words known as "typical yuqi zhuci" that are commonly used at the end of speeches in the Chinese language carry multiple grammatical functions. The use of such abstract words is not applicable in the Malay language. The current study identifies the function of each typical yuqi zhuci in the Chinese language and examines its accessibility in its translation into Malay. The study utilises the definition of yuqi zhuci by Zhang Bin (2010), the categorisation of yuqi zhuci by Shao Jingmin (2007) as well as the categorisation of typical yuqi zhuci in Chinese sentences, also by Zhang Bin (2010) in carrying out the analysis. A total of 527 sentences containing typical yuqi zhuci were extracted manually for the analysis. Each typical yuqi zhuci is categorised according to how it is employed in different types of sentences, namely, interrogative sentence (29.6 percent), imperative sentence (4.6 percent), affirmative sentence (62.6 percent), interjective sentence (2.7 percent) and ellipsis sentence (0.5 percent). To avoid duplicate analysis of data that are of similar patterns, only 35 items containing typical yuqi zhuci were used as research data. The results of the study show that the different functions of the six types of typical yuqi zhuci are specific in nature, based on how they are used in various types of Chinese sentences. The findings suggest that such functions can be delivered from the source language to Malay language via contextual consideration. And when typical yuqi zhuci cannot be fully expressed in the target language, it is due to the emic difference between the source language and the target language, as well as issues of inappropriate translation. The findings suggest that the transference of functions of typical yuqi zhuci in Chinese-Malay translation depends largely on identifying the functions of the typical yuqi zhuci present in the source text, story context, the speaker's intention as well as the accuracy of the speaker's tone. Evidently, the transference of functions of the typical yuqi zhuci does not rely on finding lexical equivalent from the target text.
\end{abstract}

Keywords and phrases: typical yuqi zhuci, abstract word, grammatical function, transference, Chinese-Malay translation

\title{
Pengenalan
}

Sarjana pengajian penterjemahan yang menggagaskan teori penterjemahan berasaskan linguistik seperti Nida dan Taber (1982), Larson (1984), Newmark (1988) dan Jakobson (2004) rata-rata mentakrifkan penterjemahan sebagai proses pemindahan yang berlaku daripada bahasa sumber kepada bahasa sasaran. Mereka berpendapat bahawa unsur yang menjadi objek pemindahan ialah makna dan bentuk, dan makna sentiasa diutamakan daripada bentuk. Larson (1984) 
membahagikan makna kepada dua aspek, iaitu makna tatabahasa dan makna leksikal. Makna tatabahasa ialah makna kata-kata yang mendukung fungsi nahu tetapi tidak mempunyai makna rujukan seperti kata sendi "di" dan "pada" serta kata hubung "dan" dan "yang", manakala makna leksikal ialah makna kata-kata yang mengungkapkan makna rujukan seperti kata nama "kerusi" dan "kereta" serta kata adjektif "merah" dan "cantik". Makna tatabahasa ini penting sebagai penjalin yang menghubungkaitkan makna keseluruhan wacana. Namun demikian, makna tatabahasa kurang mendapat perhatian khusus dalam penyelidikan penterjemahan.

Hasil kepustakaan menunjukkan bahawa kajian tentang makna tatabahasa yang dizahirkan melalui kata abstrak dalam penterjemahan bahasa Cina (BC)-bahasa Melayu (BM) adalah terhad jika dibandingkan dengan penyelidikan bidang terjemahan BC-BM daripada segi makna leksikal melalui kata konkrit. Kajian lepas menunjukkan bahawa penyelidikan kata konkrit banyak diusahakan. Contohnya, kajian tentang kata kerja (Goh Sang Seong dan Mashudi 2004; Goh Sang Seong 2011), kata nama dan kata sifat (Lau Yoke Lian 2009), kata ganti nama (Tan Tiam Lai dan Norul Haida 2013) dan kata nama khas (Ooi Hoey Boey 2013; Goh Sang Seong 2013) telah dijalankan sekali gus menghasilkan dapatan baharu tentang kaedah penterjemahan pelbagai golongan kata konkrit. Sebaliknya, kajian tentang kata abstrak yang pernah dijalankan adalah terhad dan masih banyak lompang yang perlu diisi. Setakat ini, cuma kajian tentang kata sendi (Goh Sang Seong 2014) yang ditemui dalam sorotan kepustakaan. Yang terbaharu, Jennica Chin Ai Ai dan Goh Sang Seong (2017) telah menjalankan kajian tentang kaedah penterjemahan yuqi zhuci tipikal tetapi bukan pemindahan fungsi yuqi zhuci tipikal. Oleh itu, penerokaan pemindahan makna tatabahasa atau fungsi yuzi zhuci dalam terjemahan BC-BM amat diperlukan untuk menambahkan penemuan ilmu baharu, khususnya yang bersifat fundamental dalam penterjemahan BC-BM.

Kajian ini memanfaatkan karya terjemahan Cerpen Sastera Mahua III: Dalam Hujan Renyai (DHR) sebagai korpus. Antologi cerpen ini diterbitkan oleh Dewan Bahasa dan Pustaka pada tahun 2000 dan mengandungi 14 buah cerpen kontemporari yang menceritakan pelbagai jenis latar belakang kehidupan dan kerjaya. Pemerhatian awal ke atas cerpen-cerpen tersebut sepertimana Contoh 1 yang dibincangkan berikutnya menunjukkan bahawa yuqi zhuci sememangnya menimbulkan kesukaran dalam penterjemahan.

Yuqi zhuci ialah transliterasi yang terbentuk daripada kata 语气 (yuqi) yang bermaksud nada dan 助词 (zhuci) yang bermakna kata bantu. Menurut Zhang Bin (2010, 860), yuqi zhuci merupakan penghubung dalam komunikasi bahasa yang berfungsi untuk menzahirkan sikap atau emosi penutur yang hendak diberikan penegasan dalam penyampaian sesuatu mesej. Di samping menyampaikan mesej 
dalam komunikasi lisan seharian, yuqi zhuci digunakan bersama dalam ayat untuk merealisasikan fungsi tertentu dalam penyampaian sikap dan emosi penutur dalam ujaran. Pada pendapat Qi Huyang (2002) pula, majoriti pakar linguistik BC bersetuju bahawa semua unit tambahan, iaitu kata-kata yang tidak mendukung makna leksikal tetapi membawa fungsi bagi penyampaian emosi pada sesuatu ayat atau ujaran secara automatik dikenali sebagai yuqi zhuci. Qi Huyang (2002) melakukan perbincangan yang lebih sistematik mengenai yuqi zhuci dalam kajian beliau. Beliau mendefinisikan yuqi sebagai kesedaran subjektif yang diselitkan dalam sesuatu ujaran penutur melalui tambahan komponen tatabahasa terhadap struktur sesuatu ayat. Kesedaran subjektif tersebut mencerminkan sikap dan emosi penutur. Menurut Fu You (1997, 93), yuqi zhuci merupakan sejenis fenomena linguistik yang khusus dalam BC kerana makna yang disampaikan melalui yuqi zhuci adalah amat halus dan tidak mudah untuk dijelaskan. Fenomena penggunaan yuqi zhuci dapat diperlihatkan melalui Contoh 1 (daripada korpus kajian ini) berikut:

\section{Contoh 1:}

Teks sumber: 老板，这一大缸水，有什麼作用啊?

Transliterasi: [laoban] [zhe] [yi] [da] [gang] [shui] [you] [sheme] [zuoyong a] Glos: [Tauke] [ini] [satu] [besar] [tong] [air] [ada] [apa] [gunanya yuqi zhuci a]

Teks sasaran: Tauke, tempayan yang penuh dengan air ini, apa gunanya?

Contoh 1 merupakan ayat pertanyaan yang ditujukan kepada pendengar, iaitu seorang tauke. Dalam konteks ini, seorang pelanggan muda menanya pendengar yang lebih tua usianya mengenai sebuah tempayan yang diletakkan di dalam kedainya. Dalam teks sumber, penutur menggunakan yuqi zhuci "a" pada penghujung ayat. Menurut Zhang Bin (2010), yuqi zhuci "a" berfungsi mengurangkan nada "paksaan" dalam soalan yang ditujukan kepada pendengar. Oleh itu, dapat dilihat bahawa penggunaan yuqi zhuci "a" adalah penting di sini kerana tanpanya, ujaran tersebut akan kedengaran seperti penutur sedang menyoal siasat pendengar. Perhatikan perbandingan kedua-dua ayat dalam Jadual 1 berikut. 
Jadual 1. Perbandingan fungsi yuqi zhuci 'a' dalam ayat BC

1(a). Dengan yuqi zhuci “a":

Teks sumber: 老板, 这一大缸水, 有什麼作用啊?

Glos: $\quad$ [Tauke], [ini] [satu] [besar] [tong] [air], [ada] [apa] [gunanya] [yuqi zhuci a]?

Implikasi ayat: (Pertanyaan dikemukakan kerana rasa ingin tahu.)

Nada penutur adalah lembut dan tidak menunjukkan nada paksaan.

1(b). Tanpa yuqi zhuci "a":

Teks sumber: 老板, 这一大缸水, 有什麼作用?

Glos: $\quad$ [Tauke], [ini] [satu] [besar] [tong] [air], [apa] [gunanya]?

Implikasi ayat: (Untuk menuntut jawapan bagi soalan yang ditanya dengan terus-terang.)

Nada penutur tanpa yuqi zhuci menjadikan soalan tersebut kedengaran seperti

soal siasat. Ia juga boleh membawa nada was-was atau syak jika pengujar

menyebut ayat itu secara perlahan.

Perbandingan ayat 1(a) dan 1(b) dalam Jadual 1 menunjukkan bahawa yuqi zhuci "a" dapat dikatakan merupakan satu "penambahan" pilihan yang tidak semestinya dimasukkan dalam ayat. Penelitian menunjukkan bahawa ayat pertanyaan dalam ayat 1(a) tetap merupakan sebuah ayat lengkap, dengan atau tanpa yuqi zhuci "a". Namun, penambahan yuqi zhuci "a" dapat mengubah suasana ayat tersebut. Hal ini adalah kerana fungsi yuqi zhuci "a" dalam ayat $\mathrm{BC}$ adalah untuk melembutkan nada penutur. Seperti yang dapat diperhatikan dalam Contoh 1, perbandingan antara kedua-dua ayat itu menunjukkan bahawa pengguguran yuqi zhuci "a" dalam ayat 1(b) sedikit sebanyak menjejaskan nada asal pengujar dalam teks sumber.

Walaupun impak tersebut kelihatan tidak ketara kepada pembaca teks sasaran, namun fungsi tersebut sememangnya menjadi suatu yang unik dalam tatabahasa BC. Dalam Contoh 1, ayat tersebut diujarkan oleh seorang pemuda kepada seorang tauke yang berusia lebih tua. Secara logiknya, apabila seorang pendengar yang lebih berusia ditujui soalan yang disampaikan dengan nada terus-terang dan tidak formal oleh pihak yang lebih muda usianya, pendengar tentunya akan berasa terkejut, malahan tersinggung. Lebih-lebih lagi faktor usia diberikan kepentingan dalam sosiobudaya Cina dan Melayu. Pada masa yang sama, jika pertanyaan tersebut disampaikan dengan nada yang lembut, maka respons yang akan diberikan oleh pendengar tentunya akan lebih ramah. Hal ini menunjukkan bahawa pentingnya penggunaan yuzi zhuci dalam BC. Namun, pemerhatian awal menunjukkan bahawa dalam teks terjemahan, yuqi zhuci "a" tidak diterjemahkan dan sekali gus menyebabkan fungsi tersebut tidak berjaya disampaikan. Kegagalan penyalinan semula fungsi tersebut ke dalam teks sasaran boleh menyebabkan kepincangan makna emosi keseluruhan teks. 
Pemerhatian awal ini menunjukkan bahawa sebenarnya masalah yang wujud ialah kesukaran menterjemah fungsi yuqi zhuci kerana fungsi tatabahasa tersebut adalah jarang atau hampir tidak digunakan dalam bahasa sasaran, iaitu BM. Memandangkan yuqi zhuci merupakan komponen tatabahasa yang tidak mempunyai makna leksikal, isu yang hendak diteliti dalam makalah ini adalah sama ada terjemahan yang dilakukan berjaya atau tidak memelihara fungsi yuqi zhuci yang terkandung dalam teks sumber.

\section{Sorotan Kepustakaan}

Pada awal tahun 1989, Ma Jianzhong, dalam penulisannya yang bertajuk Mashi Wentong (Rampaian Sastera Aliran Ma) menyatakan bahawa yuqi zhuci adalah ciri unik BC (Dai Zhaoming 2008, 1). Dalam kajian Ma Jianzhong (1989, 323), beliau menyatakan bahawa yuqi zhuci ialah fenomena bahasa yang merupakan milikan tunggal BC. Berkaitan dengan pernyataan beliau, terdapat sarjana-sarjana yang tidak bersetuju dengan pandangan tersebut, terutama golongan yang menjalankan penyelidikan merentasi linguistik. Menurut Dai Zhaoming (2008, 1), antara sarjana tersebut ialah Liu Danqing (2003) yang berpendapat bahawa pandangan tersebut "tidak dapat berdiri sendiri jika diselidik daripada sudut penyelidikan merentasi linguistik". Walaupun beliau berpendapat demikian, namun Liu tidak berjaya memberikan bukti yang menunjukkan bahawa yuqi zhuci juga wujud dalam bahasa-bahasa lain kerana pernyataan beliau dibuat hanya berasaskan salah satu bab dalam manuskrip bertajuk "Kajian mengenai jenis yuqi zhuci dalam tatabahasa bahasa Cina" yang ditulis oleh Lu Jingguang (2001). Hasil kajian Lu Jingguang (2001) menunjukkan bahawa yuqi zhuci juga wujud dalam bahasa yang tidak mempunyai perkaitan dengan $\mathrm{BC}$, contohnya bahasa daripada benua Asia, Eropah, Amerika Syarikat dan sebagainya.

Pada pendapat Lu Jingguang (2001), berikutan pemahaman orang ramai terhadap perbezaan tipologi bahasa yang semakin meluas, perspektif mereka juga kian menjadi semakin terbuka dan maju. Tambah beliau, keunikan yuqi zhuci dalam BC seperti yang diperkatakan oleh para sarjana lambat-laun menjadi pudar kerana dapatan kajian dalam bidang merentasi linguistik pada masa hadapan akan membuktikan bahawa penggunaan yuqi zhuci juga wujud dalam kebanyakan bahasa di dunia ini.

Sejak perdebatan dalam buku Mashi Wentong oleh Ma Jianzhong (1989), usaha penerokaan ciri-ciri tatabahasa $\mathrm{BC}$ menjadi salah satu matlamat penting dalam penyelidikan tatabahasa $\mathrm{BC}$ dan banyak sarjana telah giat berusaha dalam menyumbang kepada bidang ini (Wu Fuxiang 2012, 1). Salah satu kajian penting yang membuka ruang kepada penyelidikan yuqi zhuci dalam tatabahasa BC adalah 
melalui dapatan kajian yang dikemukakan oleh Wang Li. Pada tahun 1950, Wang Li, seorang pakar bahasa yang terkenal, menyatakan bahawa tiada yuqi zhuci dalam tatabahasa BC kuno. Namun, Dai Zhaoming (2006) tidak bersetuju dengan pendapat Wang Li lalu mengutarakan bahawa yuqi zhuci “a” (啊) dalam tatabahasa BC moden merupakan terbitan daripada yuqi zhuci "ye" (也) dalam tatabahasa BC kuno. Beliau menjelaskan bahawa terbitan tersebut tidak berlaku secara langsung tetapi melalui beberapa peringkat. Beliau percaya bahawa kajian yuqi zhuci menyumbang kepada kajian sejarah tipologi yuqi zhuci dalam tatabahasa BC, dan penyelidikan yang lebih menyeluruh haruslah digiatkan.

Berdasarkan himpunan sorotan kepustakaan yang telah dijalankan oleh Dai Zhaoming (2008) dan Zhang Bin (2010), mereka menyimpulkan bahawa yuqi zhuci dapat ditakrifkan sebagai "bentuk luaran semantik untuk menerangkan mood". Definisi ini sebenarnya dikembangkan daripada gagasan takrifan oleh Lü Shuxiang (1982) dan Wang Li (1985).

Daripada kajian Wang Li $(1985,160)$, beliau menyatakan bahawa asalkan bentuk bahasa itu digunakan dalam penyampaian emosi yang membawa kepada implikatur, ia dikenali sebagai yuqi; manakala xuci (虚词), sejenis kata abstrak yang digunakan untuk menyampaikan nada penutur dalam pengucapan pula dikenali sebagai yuqi ci. Wang Li turut memberikan contoh seperti berikut: "a" (啊) digunakan pada penghujung ayat imperaktif untuk membawa fungsi menggesa bagi menjadikan konteks bahasa bernada serius. Dalam hal ini, beliau cuba menjelaskan bahawa yuqi berlaku hasil daripada motivasi intrinsik dan merupakan manifestasi luaran idea. Dalam kajiannya, Wang Li $(1985,160)$ cuba menekankan perkaitan antara yuqi dengan emosi. Walaupun struktur sebuah ayat menentukan makna utama dalam komunikasi, namun oleh sebab penutur yang menggunakan ayat tersebut mempunyai pandangan bersifat subjektif yang tersendiri, maka dalam proses mengujarkan sesuatu ayat itu, penutur secara langsung menghasilkan emosi subjektif semula jadi. Sentimen tersebut merupakan asas psikologi pilihan penutur dalam penentuan sikap semasa pertuturan, struktur sintaksis sesuatu ayat dan juga jenis ayat yang digunakan dalam komunikasi.

Kajian Lü Shuxiang $(1982,257)$ memaparkan bahawa yuqi mempunyai pengertian yang umum dan khusus. Pengertian umum bagi yuqi termasuklah unsur semantik dalam bahasa dan konteks bahasa. Unsur semantik dalam yuqi merujuk kepada persamaan dan perbezaan, ketetapan dan perubahan serta perbezaan antara maya dengan nyata. Konteks bahasa pula merujuk kepada nada penutur daripada segi ketegasan, kesantunan dan sebagainya. Bagi pengertian khusus pula, definisi yang diberikan adalah berdasarkan tujuan penggunaan. 
Sehubungan itu, Zhang Bin $(2010,858)$ menyenaraikan kategori yuqi yang digagaskan oleh Wang Li $(1985,160)$ dan Lü Shuxiang $(1982,257)$ seperti dalam Jadual 2 untuk dibuat perbandingan bagi memudahkan pemahaman pembaca.

Jadual 2. Perbandingan kategori yuqi antara Wang Li (1985) dengan Lü Shuxiang (1982)

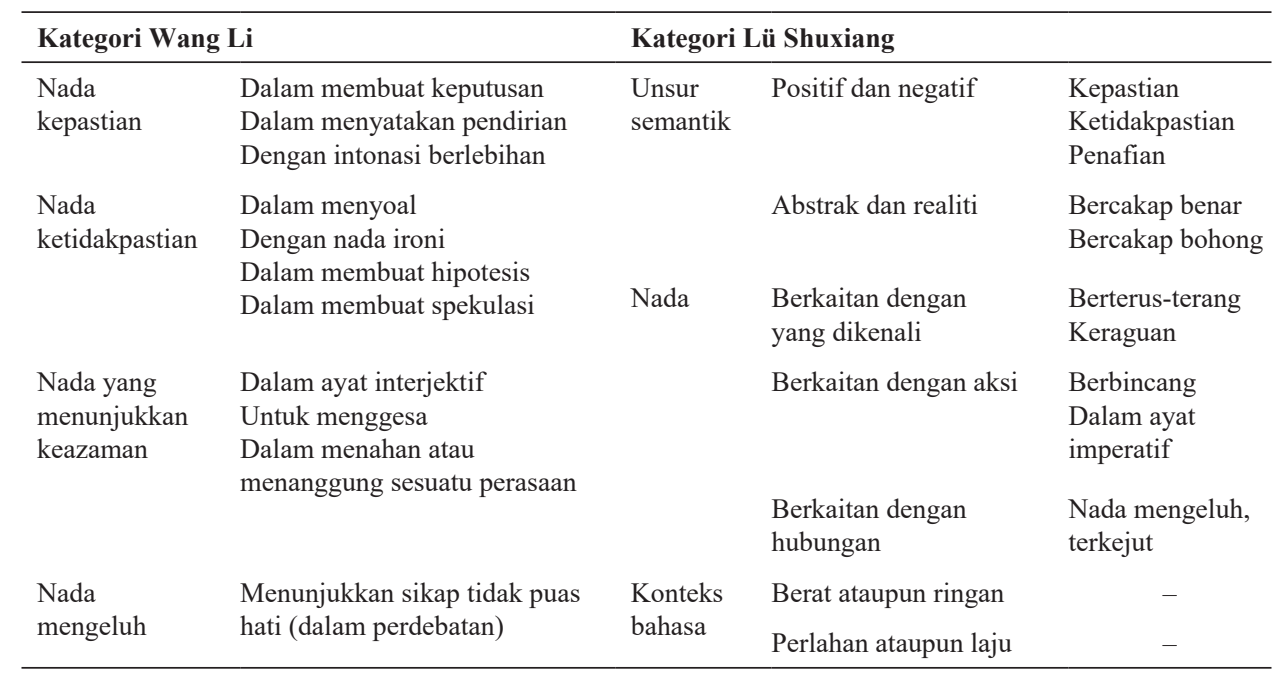

Sumber: Zhang Bin $(2010,858)$

Jadual 2 memaparkan kenyataan bahawa kedua-dua orang sarjana ini mempunyai pengkategorian yuqi yang berbeza. Dalam kategori yuqi yang disarankan oleh Wang Li (1985), beliau membahagikan fungsi yuqi kepada empat jenis penggunaan yang utama, iaitu (1) untuk menyampaikan nada kepastian, (2) untuk menyampaikan nada ketidakpastian, (3) untuk menyampaikan nada yang membawa keazaman, dan (4) untuk menyampaikan nada keluhan. Kategori Wang Li ini dijelaskan dengan lebih perinci melalui kelaziman penyampaian yuqi yang mempunyai fungsi tersendiri. Menurut Wang Li, yuqi yang membawa nada kepastian biasanya digunakan oleh penutur apabila hendak menyatakan pendirian, membuat keputusan dan kadangkala juga digunakan untuk menunjuk-nunjuk. Sebaliknya, yuqi yang menunjukkan nada ketidakpastian digunakan apabila penutur ingin menyoal, menyatakan sesuatu dengan nada ironi, membuat spekulasi atau apabila penutur ingin menggesa. Seterusnya, yuqi yang menunjukkan nada keazaman biasanya digunakan dalam ayat interjektif dan fungsi utamanya adalah untuk menunjukkan emosi penutur yang cuba menahan atau menanggung sesuatu perasaan. Selain itu, emosi penutur yang tidak puas hati dapat disampaikan dengan yuqi yang membawa nada keluhan. Dalam kategori yuqi yang digagaskan oleh Lü Shuxiang (1982) pula, beliau membahagikan yuqi kepada tiga kategori utama, iaitu (1) berdasarkan unsur semantik, (2) nada, dan (3) berdasarkan konteks bahasa. Menurut Lü Shuxiang, 
unsur semantik yang dimaksudkan merujuk kepada impak fungsi yuqi dalam ayat dan dibahagikan dengan lebih perinci kepada dua subkategori, iaitu (1) positif dan negatif, dan (2) abstrak dan realiti. Apabila digunakan dalam subkategori positif dan negatif, ia membawa fungsi penentuan nada penutur, sama ada ayat yang diujarkan itu adalah dengan nada kepastian, ketidakpastian atau penafian; manakala bagi subkategori abstrak dan realiti pula, ia membawa fungsi penentuan sama ada penutur bercakap benar atau bohong dalam sesuatu ayat. Kategori kedua, iaitu nada pula dibahagikan kepada tiga perkaitan, iaitu (1) apabila topik yang dibincangkan berkaitan dengan pendengar yang dikenali, nada penutur kemungkinan bersifat terus-terang ataupun dengan keraguan, (2) apabila ayat yang diujar melibatkan aksi, ia biasanya digunakan dalam ayat imperatif, dan (3) apabila topik yang dibincangkan berkaitan dengan perasaan, maka nada penutur berkemungkinan membawa unsur mengeluh ataupun terkejut. Bagi kategori ketiga pula, iaitu konteks bahasa, menurut Lü Shuxiang (1982), nada penutur dapat ditentukan berdasarkan konteks ayat dan lazimnya disampaikan melalui dua jenis intonasi, iaitu (1) berat atau ringan, dan (2) perlahan atau laju.

Menurut Zhang Bin (2010, 858), hasil kajian Wang Li dan Lü Shuxiang mempunyai satu persamaan, iaitu kedua-dua pengkategorian ini dapat dijadikan panduan umum dalam teori tatabahasa kerana pengkategorian tersebut dibuat berdasarkan analisis korpus BC. Tambah beliau, kedua-dua penyelidikan ini memainkan peranan yang besar dalam hala tuju kajian masa hadapan. Walau bagaimanapun, keduadua gagasan ini mempunyai beberapa masalah. Pertama, ia membincangkan isuisu $\mathrm{BC}$ kuno bersama dengan $\mathrm{BC}$ moden, lantas fokusnya tidak jelas kerana $\mathrm{BC}$ kuno berbeza daripada $\mathrm{BC}$ moden. Kedua, kebanyakan data daripada korpus dan ilustrasi yang digunakan dalam analisis fungsi yuqi dalam kajian-kajian tersebut agak ketinggalan zaman dan penggunaan bahasa pada zaman itu adalah jauh berbeza daripada keadaan kini. Oleh itu, pemerhatian dan penerangan baharu haruslah dilakukan untuk mengemas kini dapatan kajian dalam bidang ini.

\section{Kerangka Teori dan Kaedah Penyelidikan}

Makalah ini membincangkan dapatan kajian yang memanfaatkan kerangka teori berikut: definisi yuqi zhuci dan fungsi yuqi zhuci tipikal berdasarkan jenis ayat kehadirannya yang disarankan oleh Zhang Bin (2010) dan pengkategorian yuqi zhuci oleh Shao Jingmin (2007).

Zhang Bin (2010, 860) menjelaskan bahawa yuqi zhuci merupakan pengantar dalam bahasa yang digunakan untuk menyampaikan sikap atau emosi penutur yang ditekankan dalam penyampaian mesej. Shao Jingming $(2007,5)$ membincangkan pengkategorian kata dalam sistem tatabahasa. Menurut beliau, dalam tatabahasa 
BC, kata terbahagi kepada kata konkrit (实词 shici) dan kata abstrak (虚词 xuci) berdasarkan struktur komponen sintaksis. Menurut beliau, kata konkrit merujuk kepada perkataan yang mempunyai erti nyata dan dapat berdiri sendiri, manakala kata abstrak tidak memiliki erti jelas dan tidak dapat berdiri sendiri. Beliau mengulas lebih lanjut dengan memberikan contoh kata konkrit, iaitu kata nama, kata kerja, kata adjektif, kata bilangan, kata ganti nama dan kata keterangan, manakala kata abstrak pula merangkumi kata depan, kata hubung, yuqi zhuci dan kata seru.

Pada beliau, yuqi zhuci dapat dibahagikan kepada dua kategori utama: kategori pertama adalah yuqi zhuci tipikal yang mempunyai frekuensi penggunaan yang lebih tinggi dalam BC. Terdapat enam kata yuqi zhuci tipikal, iaitu "a" (啊), “ma” (吗), “ba” (吧), “ne” (呢), “le” (了) dan “de” (的); kategori kedua pula adalah yuqi zhuci tidak tipikal yang lazimnya hanya digunakan dalam ayat tertentu dan penggunaannya adalah lebih khusus, iaitu “ma” (嘛), “me” (嚜), “li” (哩), “yo” (吆), “bei” (呗), “ne” (呐), “la” (啦), “na” (呐) dan “lou” (喽). Kajian ini memfokus pada analisis pemindahan fungsi yuqi zhuci tipikal daripada teks sumber BC kepada teks sasaran BM kerana frekuensi penggunaannya adalah lebih tinggi jika dibandingkan dengan yuqi zhuci tidak tipikal sepertimana yang dinyatakan oleh Zhang Bin (2010, 247).

Walaupun kategori yuqi zhuci tipikal hanya merangkumi yuqi zhuci “a” (啊), yuqi zhuci “ma” (吗), yuqi zhuci “ba” (吧), yuqi zhuci “ne” (呢), yuqi zhuci “le" (了) dan yuqi zhuci "de" (的), akan tetapi, penggunaan keenam-enam yuqi zhuci ini agak kompleks dan secara umumnya merangkumi pelbagai fungsi spesifik dalam tatabahasa BC. Menurut Zhang Bin (2010), secara umumnya, yuqi zhuci "a" lazimnya digunakan oleh penutur untuk menyampaikan luahan seperti kejutan, pujian, nasihat, amaran atau gesaan. Ia juga berfungsi sebagai pelembut nada. Fungsi yuqi zhuci "a" yang sebenar hanya dapat ditentukan berdasarkan konteks ayat melalui nada dan emosi yang ingin disampaikan oleh penutur. Sementara itu, yuqi zhuci "ma" berfungsi mendapatkan jawapan daripada pendengar. Yuqi zhuci "ba" pula boleh digunakan dalam konteks yang berbeza dan peranan asasnya adalah untuk melembutkan nada penutur semasa mengemukakan ayat mendesak, perintah dan sebagainya. Yuqi zhuci "ne" berfungsi sebagai kata abstrak yang menandakan/menyoal tentang sesuatu kegiatan yang sedang berlangsung. Seterusnya, yuqi zhuci "le" adalah lebih spesifik kerana ia berhubung kait dengan perspektif penutur dalam penyampaian sesuatu maklumat, dan biasanya digunakan dalam ayat yang menggambarkan sesuatu peristiwa yang telah berlaku. Bagi yuqi zhuci "de", penutur menggunakannya untuk menunjukkan nada penegasan dalam pertuturan. Walau bagaimanapun, fungsi yuqi zhuci tipikal berubah berdasarkan jenis ayat yang menerima kehadirannya. Oleh itu, kajian ini turut memanfaatkan gagasan fungsi yuzi zhuci tipikal berdasarkan jenis ayat yang dikemukakan oleh Zhang Bin (2010) sepertimana yang dirumuskan dalam Jadual 3. 
Jadual 3. Fungsi yuqi zhuci tipikal berdasarkan jenis ayat BC oleh Zhang Bin (2010)

\begin{tabular}{cl}
\hline Yuqi zhuci tipikal & Fungsi \\
\hline $\begin{array}{c}\text { Ayat pertanyaan } \\
\text { a (啊) }\end{array}$ & Soalan pilihan; rujukan khusus; mempunyai unsur marah \\
ba (吧) & Membuat sangkaan; nada rendah \\
ne (呢) & Soalan pilihan; rujukan khusus; pernyataan retorik atas sebab yang jelas \\
ma (吗) & Soalan pilihan; nada lebih tinggi \\
Ayat kepastian & \\
a (啊) & Membuat penjelasan; mengingatkan seseorang tentang sesuatu perkara \\
ba (吧) & Unsur terpaksa \\
ne (呢) & Menokok tambah; membuat perbandingan \\
de (的) & Penegasan nada \\
le (了) & Kepastian terhadap sesuatu perkara \\
Ayat imperatif & \\
a (啊) & Mendesak; mengingatkan seseorang tentang sesuatu perkara \\
ba (吧) & $\begin{array}{l}\text { Membuat permintaan; mendesak; mengingatkan seseorang tentang } \\
\text { Ayat interjektif }\end{array}$ \\
a (啊) & Mesuatu perkara \\
\hline
\end{tabular}

Jadual 3 menunjukkan fungsi yuqi zhuci tipikal dalam empat jenis ayat BC yang utama, iaitu ayat pertanyaan, ayat imperatif, ayat kepastian dan ayat interjektif. Ayat pertanyaan ialah ayat yang mengujarkan sesuatu kenyataan atau pendapat pengujar. Ayat imperatif ialah ayat yang mengujarkan permintaan atau arahan pengujar. Ayat kepastian pula ialah ayat yang mengujarkan kepastian pengujar tentang sesuatu perkara atau objek, manakala ayat interjektif ialah ayat yang mengujarkan perasaan seperti kegembiraan, kesedihan, ketakutan dan kebencian pengujar. Topik dalam sesuatu ayat pada dasarnya merupakan intipati teras dalam komunikasi. Namun, pandangan subjektif pengujar lazimnya dizahirkan melalui penggunaan pelbagai jenis yuqi zhuci tipikal dalam bentuk ayat yang berbeza mengikut fungsi yang tersendiri. Jadual 3 menunjukkan bahawa bukan semua yuqi zhuci tipikal dapat dipadankan dan digunakan dalam semua jenis ayat kerana fungsi setiap yuqi zhuci tipikal adalah khusus. Sebagai contoh, dalam ayat pertanyaan, terdapat empat jenis yuqi zhuci tipikal, iaitu "a", "ba", "ne" dan "ma" yang boleh digunakan untuk memerikan fungsi yang berbeza tetapi dalam ayat imperatif pula, hanya dua jenis yuqi zhuci tipikal, iaitu "a" dan "ba" boleh digunakan untuk menyampaikan nada dan emosi pengujar yang tersirat. 
Analisis ini dijalankan dengan memanfaatkan dua kaedah, iaitu kaedah kepustakaan dan analisis deskriptif yang berdasarkan konteks teks serta perbandingan teks. Kaedah kepustakaan memfokus pada pemerolehan sumber dan buku rujukan berbentuk ilmiah serta peninjauan kajian lepas yang berkaitan dengan topik kajian bagi penentuan definisi dan bentuk analisis.

Bagi kaedah analisis dan perbandingan teks pula, pengkaji:

1. Membaca, mengenal pasti dan menganalisis yuqi zhuci tipikal yang digunakan dalam teks sumber berdasarkan pengkategorian yuqi zhuci oleh Shao Jingmin (2007) serta definisi dan fungsi yuqi zhuci tipikal oleh Zhang Bin (2010);

2. Mengumpul semua yuqi zhuci tipikal secara manual dan padanan terjemahannya daripada Cerpen Sastera Mahua III: Dalam Hujan Renyai (DHR).

3. Mengklasikifasi data yang mengandungi yuqi zhuci tipikal mengikut fungsi yuqi zhuci tipikal yang disarankan oleh Zhang Bin (2010);

4. Menganalisis data yuqi zhuci tipikal yang disenaraikan dalam perkara (3) berdasarkan fungsi yuqi zhuci tipikal dalam ayat BC oleh Zhang Bin (2010) dengan melakukan perbandingan sama ada fungsi yuqi zhuci tipikal dalam teks sumber kesampaian atau tidak ke dalam teks sasaran;

5. Membuat rumusan dapatan kajian.

Hasil daripada analisis, satu rumusan dapatan kajian dapat dirumuskan untuk menghuraikan fungsi yuqi zhuci tipikal dan ketersampaiannya dalam terjemahan DHR.

Data kajian dikutip secara manual daripada cerpen sastera Mahua bertajuk Cerpen Sastera Mahua III: Dalam Hujan Renyai yang diterbitkan oleh Dewan Bahasa dan Pustaka pada tahun 2000. Daripada 527 data yuqi zhuci tipikal yang hadir dalam teks kajian, sebanyak 22 data menggunakan yuqi zhuci “a" (啊), 85 data menggunakan yuqi zhuci “ma” (吗), 39 data menggunakan yuqi zhuci “ba” (吧), 58 data menggunakan yuqi zhuci "ne" (呢), 210 data menggunakan yuqi zhuci “le" (了) dan 113 data menggunakan yuqi zhuci "de" (的). Jumlah 527 data tersebut merupakan bilangan kekerapan kehadiran yuqi zhuci tipikal dalam teks kajian yang diambil dan dikategorikan mengikut tipologi ayat BC oleh Zhang Bin (2010), iaitu ayat pertanyaan (156 data, 29.6 peratus), ayat imperatif ( 24 data, 4.6 peratus), ayat kepastian (330 data, 62.6 peratus), ayat interjektif (14, 2.7 peratus) dan ayat elipsis 
( 3 data, 0.5 peratus; ayat ini ditambah oleh pengkaji berdasarkan pemerhatian yang dilakukan pada data; ayat elipsis dalam kajian ini merujuk kepada ayat yang mempunyai bentuk yang lebih pendek dan diakhiri dengan penanda elipsis "..." kerana bahagian tertentu dalam ayat itu sengaja ditiadakan). Daripada jumlah tersebut, didapati bahawa terdapat yuqi zhuci tipikal yang mempunyai penggunaan yang melebihi sekali. Oleh itu, bagi mengelakkan pengulangan data yang sama sifatnya, satu data diambil secara rawak daripada setiap jenis yuqi zhuci tipikal yang berbeza fungsi dan sifat ketersampaiannya dalam setiap kategori yuqi zhuci tipikal untuk dianalisis secara teliti. Jadual 4 menunjukkan pemilihan 35 data yang digunakan dalam kajian ini.

Jadual 4. Pemilihan 35 data daripada $D H R$ untuk tujuan analisis

\begin{tabular}{lcccccc}
\hline \multirow{2}{*}{$\begin{array}{l}\text { Jenis ayat } \\
\text { dalam BC }\end{array}$} & $\begin{array}{c}\text { a } \\
\text { (啊) }\end{array}$ & $\begin{array}{c}\text { ma } \\
(\text { 吗 })\end{array}$ & $\begin{array}{c}\text { ba } \\
\text { (吧) }\end{array}$ & $\begin{array}{c}\text { ne } \\
(\text { 呢 })\end{array}$ & $\begin{array}{c}\text { le } \\
(\text { 了 })\end{array}$ & $\begin{array}{c}\text { de } \\
\text { (的) }\end{array}$ \\
\hline Ayat pertanyaan & 2 & 4 & 3 & 7 & 2 & 1 \\
Ayat imperatif & 1 & 0 & 1 & 0 & 0 & 0 \\
Ayat kepastian & 1 & 0 & 2 & 1 & 3 & 1 \\
Ayat interjektif & 1 & 0 & 0 & 0 & 3 & 1 \\
Ayat elipsis & 0 & - & - & - & 1 & - \\
\hline Jumlah & 5 & 4 & 6 & 8 & 9 & 3 \\
\hline
\end{tabular}

\section{Dapatan Kajian dan Perbincangan}

Dapatan kajian menunjukkan bahawa fungsi keenam-enam jenis yuqi zhuci tipikal dalam teks sumber adalah sejajar dengan definisi fungsi yuqi zhuci tipikal yang disarankan oleh Zhang Bin (2010). Jadual 5 menunjukkan rumusan ringkas tentang fungsi yuqi zhuci tipikal dalam terjemahan $D H R$.

Daripada 35 data DHR yang dianalisis, 27 data menunjukkan terjemahan fungsi yuqi zhuci tipikal kesampaian dalam teks sasaran, 4 data menunjukkan terjemahan fungsi yuqi zhuci tipikal digugurkan kerana emik bahasa Melayu tidak memerlukannya dan 4 data menunjukkan kes salah terjemah fungsi yuqi zhuci tipikal. Bagi perbincangan dalam makalah ini, keadaan terjemahan fungsi yuqi zhuci tipikal dalam terjemahan DHR akan dibincangkan seperti dalam Rajah 1. 
Jadual 5. Fungsi yuqi zhuci tipikal dalam DHR

\begin{tabular}{|c|c|c|}
\hline Yuqi zhuci tipikal & Fungsi dalam teks sumber & $\begin{array}{l}\text { Terjemahan fungsi } \\
\text { dalam teks sasaran }\end{array}$ \\
\hline \multirow[t]{4}{*}{$\mathrm{a}$ (啊) } & Melembutkan nada penutur & Data $1: \sqrt{ }$; Data $2: \sqrt{ }$ \\
\hline & Mengurangkan nada paksaan & Data 3: $\sqrt{ }$ \\
\hline & Memberikan nasihat & Data 4: $\neq$ \\
\hline & Memberikan amaran & Data 5: Ø \\
\hline \multirow[t]{2}{*}{$\mathrm{ma}$ (吗) } & Mendapatkan jawapan & Data $6: \neq$ \\
\hline & $\begin{array}{l}\text { Mendapatkan pengesahan pendengar } \\
\text { mengenai andaian yang dibuat }\end{array}$ & $\begin{array}{l}\text { Data } 7: \sqrt{ } ; \text { Data } 8: \sqrt{ } \\
\text { Data 9: } \sqrt{ }\end{array}$ \\
\hline \multirow[t]{4}{*}{ ba (吧) } & Membawa unsur spekulasi & Data $10: \sqrt{ }$; Data $15: \neq$ \\
\hline & Memberikan cadangan/memujuk & Data 11: $\sqrt{ }$ \\
\hline & Sebagai pembuka topik & Data $12: \varnothing$ \\
\hline & Melembutkan nada & Data 13: $\sqrt{ }$; Data 14: $\sqrt{ }$ \\
\hline \multirow[t]{4}{*}{ ne (呢) } & Melembutkan nada & Data $16: \sqrt{ }$ \\
\hline & Pertanyaan kepada diri sendiri & Data $17: \neq ;$ Data $22: \sqrt{ }$ \\
\hline & $\begin{array}{l}\text { Pertanyaan kepada pendengar mengenai } \\
\text { sesuatu perkara khusus }\end{array}$ & $\begin{array}{l}\text { Data } 18: \sqrt{ } ; \text { Data } 19: \sqrt{ } \\
\text { Data } 21: \sqrt{ } ; \text { Data } 23: \sqrt{ }\end{array}$ \\
\hline & Memberikan peringatan & Data 19: $\sqrt{ }$ \\
\hline \multirow[t]{4}{*}{ le (了) } & $\begin{array}{l}\text { Menandakan perkara menjadi fakta atau } \\
\text { telah berlaku }\end{array}$ & Data 24: $\sqrt{ }$; Data 25: $\sqrt{ }$ \\
\hline & Membetulkan andaian pendengar & Data 26: $\sqrt{ }$ \\
\hline & Perkembangan situasi baharu & Data 27: $\sqrt{ }$; Data 32: $\sqrt{ }$ \\
\hline & Perkembangan situasi semasa & $\begin{array}{l}\text { Data 28: } \sqrt{ } \text {; Data 29: } \sqrt{ } \\
\text { Data 30: } \sqrt{ } ; \text { Data 31: } \varnothing\end{array}$ \\
\hline $\mathrm{de}$ (的) & Nada kepastian dalam jawapan/pernyataan & $\begin{array}{l}\text { Data 33: } \sqrt{ } ; \text { Data 34: } \sqrt{ } \\
\text { Data 35: Ø }\end{array}$ \\
\hline
\end{tabular}

Nota: $\sqrt{ }=$ fungsi tercapai $\neq=$ masalah salah terjemah; $\varnothing=$ pengguguran

Daripada Rajah 1, penyalinan fungsi yuqi zhuci tipikal ke dalam BM dikatakan berjaya apabila penterjemah menterjemah teks berdasarkan konteks cerita. Sebaliknya, fungsi yuqi zhuci tipikal yang tidak kesampaian dalam terjemahan adalah disebabkan oleh emik BM yang tidak memerlukan penggunaan fungsi yuqi zhuci tipikal seperti dalam teks BC serta masalah salah terjemah. Kajian ini menunjukkan bahawa fungsi yuqi zhuci tipikal dalam terjemahan DHR terbukti digunakan untuk mencerminkan pandangan subjektif penutur (memberikan 
nasihat, peringatan, amaran, ingin mendapatkan jawapan dan pengesahan, sebagai pembuka topik, pertanyaan yang ditujukan kepada diri sendiri dan juga penutur) serta menunjukkan sikap atau emosi penutur (melembutkan nada penutur, mengurangkan nada paksaan, membawa unsur spekulasi, nada kepastian) dalam penyampaian mesej.

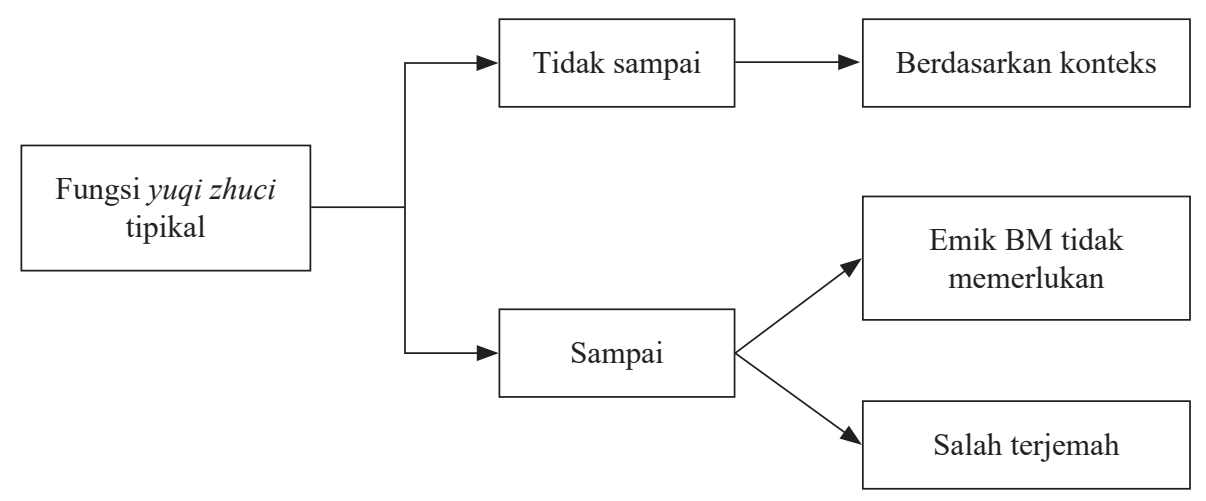

Rajah 1. Keadaan terjemahan fungsi yuqi zhuci tipikal dalam $D H R$

Berikut dipersembahkan dua contoh analisis untuk setiap keadaan terjemahan fungsi yuqi zhuci tipikal dalam DHR sepertimana yang dipaparkan dalam Rajah 1.

1. Fungsi yuqi zhuci tipikal yang kesampaian dalam teks sasaran

a. Berdasarkan konteks

Mengikut Zhang Bin (2010), yuqi zhuci "de" digunakan dalam ayat kepastian untuk mengukuhkan nada keyakinan penutur terhadap perihal yang dibincangkan. Lihat Contoh 2 berikut:

\section{Contoh 2:}

Teks sumber: 我又放声大笑, 安慰他说:“是的”。

Transliterasi: [wo] [you] [fangsheng] [daxiao] [anwei] [ta] [shuo [shide]

Glos: [Saya] [lagi] [keluarkan suara] [tertawa kuat-kuat], [memujuk] [dia] [berkata] [ya yuqi zhuci de]

Teks sasaran: Aku ketawa kuat sekali lagi, lalu menahankan perasaannya. "Ya!" (DHR 24) 
Dalam Contoh 2, jawapan ringkas “是的” (shide) merupakan kombinasi respons pendengar, iaitu perkataan "shi" dengan yuqi zhuci "de". Apabila penutur menambah yuqi zhuci "de" pada perkataan yang menandakan persetujuan seperti "shi", ia mengesahkan pernyataan/pertanyaan yang ditujukan kepada pendengar, dengan nada penuh kepastian. Berdasarkan dapatan daripada contoh lain juga, yuqi zhuci "de" biasanya digunakan untuk menunjukkan perspektif penutur yang yakin dengan kesimpulan atau pendapat yang dibuat mengenai sesuatu perihal. Untuk menyampaikan fungsi yuqi zhuci "de" dalam kes ini, penterjemah menukarkan ayat kepastian kepada ayat interjektif untuk menyampaikan nada kepastian penutur kerana konteks ayat memfokus pada nada penutur yang kedengaran sangat yakin dan pasti dengan pernyataan yang dibuat.

Seterusnya, perhatikan Contoh 3 berikut:

\section{Contoh 3:}

Teks sumber: “事实本来如此, 您又何必痴等呢?”

Transliterasi: [shishi] [benlai] [ruci] [nin] [you] [hebi] [chidengne]

Glos: [Fakta] [memang] [begitu] [awak] [pula] [mengapa] [menunggu sia-sia yuqi zhuci ne]

Teks sasaran: "Dah menjadi kenyataan seperti begini pun, fasal apa ibu masih tertunggu-tunggu secara sia-sia?" (DHR 6)

Yuqi zhuci "ne" dapat menunjukkan niat penutur untuk menyangkal pendirian/ keputusan pendengar dengan menyatakan fakta dan menyoal tujuan di sebalik pernyataan yang dibuat oleh pendengar. Biasanya, ayat sebegini juga bermaksud penutur sedar bahawa pendengar memahami dan mempunyai jawapan pada soalan yang ditujukan. Dalam konteks ayat Contoh 3, penutur mempersoalkan kedegilan pendengar, iaitu ibunya yang masih menunggu kepulangan suaminya yang meninggalkan mereka tanpa sebarang berita sejak 20 tahun yang lalu. Penggunaan yuqi zhuci "ne" dalam ayat ini berfungsi memujuk pendengar untuk berfikir masak-masak kerana penutur amat bimbang pada situasi pendengar. Tanpa yuqi zhuci "ne", ayat tersebut akan menjadi ayat pertanyaan yang biasa sahaja. Dalam teks terjemahan, penterjemah menggunakan perkataan "masih" untuk menegaskan kenyataan bahawa penantian tersebut adalah terlalu lama dan seharusnya dihentikan. Penambahan kata "masih" menunjukkan bahawa terjemahan tersebut adalah memadai dalam penyampaian fungsi yuqi zhuci "ne" yang ingin disampaikan oleh penulis teks sumber. 
2. Fungsi yuqi zhuci tipikal yang tidak kesampaian

a. Masalah salah terjemah

Fungsi asas yuqi zhuci "ma" dalam ayat pertanyaan adalah untuk mengetengahkan fokus soalan bagi menegaskan keinginan penutur untuk mendapatkan jawapan. Ayat pertanyaan sebegini biasanya dalam bentuk kepastian. Teliti Contoh 4 berikut:

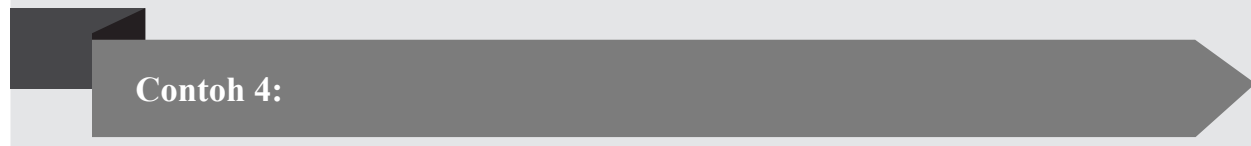

Teks sumber: 我有这个荣幸请你一道去观赏吗?

Transliterasi: [wo] [you] [zhege] [rongxing] [qing] [ni] [yidao] [qu] [guanshangma]

Glos: [Saya] [ada] [yang ini] [penghormatan] [mempelawa] [awak] [samasama] [pergi] [menonton yuqi zhuci ma]

Teks sasaran: Bertuahlah saya jika awak dapat pergi menonton bersamasama! (BD, BN \& P 305)

Contoh 4 merupakan ayat yang menggunakan yuqi zhuci "ma" pada penghujung ayat pertanyaan. Fungsi yuqi zhuci "ma" dalam ayat ini adalah untuk mengajak pendengar menghadiri sebuah persembahan dan keinginan penutur direalisasikan apabila penutur cuba mendapatkan jawapan daripada pendengar. Jika diteliti, terjemahan ayat ini adalah berbeza dengan ayat dalam teks sumber kerana penterjemah menukarkan ayat pertanyaan kepada ayat interjektif.

Berdasarkan konteks yang dijelaskan dalam teks sumber, penutur berniat untuk mengajak dan seterusnya mendapatkan persetujuan pendengar untuk menghadiri sebuah persembahan bersama-sama dengannya. Akan tetapi, ayat terjemahan yang menjadi ayat interjektif memberikan kesan yang berbeza pula. Dalam teks terjemahan, penutur bagaikan sengaja membuat andaian di hadapan pendengar untuk memberikan isyarat atau cadangan dan bukannya kedengaran seperti mempelawa pendengar. Terjemahan ini adalah tidak tepat dan terjemahan yang lebih sesuai adalah dengan mengekalkan pertanyaan tersebut dengan menggunakan perkataan seperti "sudikah" pada permulaan ayat untuk menyalin fungsi yuqi zhuci "ma" yang berfungsi mempelawa pendengar. 
Seperti yuqi zhuci "ma", yuqi zhuci "ba" juga boleh dipersembahkan dalam bentuk ayat pertanyaan dan memperlihatkan fungsi yang berbeza. Perhatikan Contoh 5 berikut:

\section{Contoh 5:}

Teks sumber: “比往常坏些吧?”

Transliterasi: [bi] [wangchang] [huai] [xieba]

Glos: [Lebih] [selama ini] [teruk] [sedikit yuqi zhuci ba]?

Teks sasaran: "Buruk daripada musim-musim biasa?” (MYEMT 127)

Yuqi zhuci "ba" dalam Contoh 5 digunakan dalam soalan retorik. Pemerhatian fungsi yuqi zhuci "ba" di sini secara spesifiknya menunjukkan bahawa wujudnya unsur spekulasi dan dalam kes ini, bukan semata-mata sebagai pertanyaan, tetapi juga sebagai pembuka topik dalam perbualan.

Dalam konteks perbualan Contoh 5, penutur sebenarnya tahu bahawa hasil tuaian pendengar tidak memberangsangkan. Niat penutur adalah untuk membuka topik baharu yang dapat memujuk pendengar supaya mempertimbangkan cadangan penjualan tanah yang ingin dikemukakan. Bagi mencapai tujuan itu, penutur menggunakan yuqi zhuci "ba" pada penghujung ayat pertanyaan. Tanpa yuqi zhuci "ba" dalam ayat pertanyaan tersebut, ia akan menjadi soalan biasa yang mengharapkan jawapan ya atau tidak. Sebaliknya, penggunaan yuqi zhuci "ba" menjadikan makna ayat berbeza dan bersifat retorik. Dalam hal ini, terjemahan literal menyebabkan fungsi dan keseluruhan konteks ayat berubah makna. Penterjemah dikatakan menggunakan kaedah pengguguran kerana fungsi yuqi zhuci "ba" tidak diterjemahkan. Hasilnya, soalan retorik ini secara tidak langsung ditukar menjadi ayat pertanyaan yang biasa sahaja.

b. Emik BM tidak memerlukan

Selain penggunaan yuqi zhuci "a" yang biasanya berfungsi memberikan pujian, pengiktirafan dan keluhan dalam ayat interjektif yang dibincangkan oleh Zhang Bin (2010), ia juga berfungsi sebagai "peranti" untuk menarik perhatian segera daripada pihak pendengar dan menunjukkan sikap/nada penutur yang tidak sabar. Teliti Contoh 6 berikut: 


\section{Contoh 6:}

Teks sumber:「火, 救火啊！」驚惶的嘶喊聲震撼了整個「 樂園」。

Transliterasi: [huo] [jiuhuoa] [jinghuang] [de] [sihansheng] [zhenhanle] [zhengge] [leyuan]

Glos: [Api] [padamkan api yuqi zhuci a]! [panik] [punya] [jeritan] [bunyi] [telah menggegarkan] [seluruh] [taman]

Teks sasaran: “Api! Api!” Jeritan dan pekikan menggemparkan seluruh Kayangan. (IN 199)

Contoh 6 merupakan situasi yang menampakkan fungsi yuqi zhuci "a" yang digunakan oleh penutur untuk menarik perhatian dalam ayat interjektif. Memandangkan fungsi yuqi zhuci "a" adalah untuk menarik perhatian orang mengenai isu kebakaran yang berlaku pada masa itu, maka terjemahan ayat interjektif kepada ayat interjektif yang memfokus pada subjek api adalah memadai. Dalam hal ini, penterjemah menggugurkan yuqi zhuci "a" dalam ayat ini kerana emik BM tidak memerlukannya.

Seterusnya, lihat Contoh 7 berikut:

\section{Contoh 7:}

Teks sumber：他望一望腕表, 心又是一跳：糟糕！只剩下五十 分钟了!

Transliterasi: [ta] [wangyiwang] [wanbiao] [xin] [you] [shi] [yitiao] [zaogao][zhi][shengxia] [wushi] [fenzhongle]

Glos: [Dia] [melihat] [jam tangan] [hati] [lagi] [sekali] [berdebar] [celaka] [hanya] [tinggal] [lima puluh] [minit yuqi zhuci le]

Teks sasaran: Dia melihat ke arloji di tangannya, hatinya berdebar. Celaka! Hanya tinggal 50 minit. (SL 159) 
Contoh 7 menunjukkan nada kegelisahan penutur sebagai akibat kekangan masa. Fungsi yuqi zhuci "le" dalam kes ini adalah untuk menekankan bahawa penutur cuma ada masa selama 50 minit. Dalam kes ini, penterjemah juga menggugurkan item linguistik yuqi zhuci "le". Yuqi zhuci "le" digunakan dalam ayat interjektif teks sumber, iaitu apabila melaporkan suatu situasi baharu yang tidak diduga, penutur menggunakan yuqi zhuci "le" untuk memberi penekanan pada emosi dalam ayat kerana keadaan tersebut bercanggah dengan jangkaan normal pada ketika itu. Namun, yuqi zhuci "le" tidak dapat diterjemahkan ke dalam teks sasaran berikutan tiadanya padanan sejadi dalam nahu BM. Namun begitu, fungsi penegasan yuqi zhuci "le" dapat dijelmakan melalui perkataan "hanya" dalam teks sasaran.

Selain itu, hasil penelitian turut menunjukkan bahawa dapatan kajian adalah sejajar dengan pernyataan Zhang Bin (2010) yang menyatakan bahawa keenamenam jenis yuqi zhuci tipikal mempunyai fungsi spesifik yang dijelmakan melalui penggunaannya dalam empat jenis ayat $\mathrm{BC}$ yang berbeza. Empat ayat yang dimaksudkan ialah ayat pertanyaan, ayat imperatif, ayat kepastian dan ayat interjektif.

\section{Kesimpulan}

Kajian ini membuktikan bahawa yuqi zhuci tipikal yang digunakan dalam teks sumber, iaitu antologi Cerpen Sastera Mahua III: Dalam Hujan Renyai mempunyai fungsi tertentu berdasarkan jenis ayat yang digunakan, sepertimana yang disenaraikan oleh Zhang Bin (2010) dalam kajian beliau mengenai pengkategorian yuqi zhuci tipikal berdasarkan jenis ayat BC. Kajian Zhang Bin (2010) menyatakan bahawa bukan semua jenis yuqi zhuci tipikal dapat digunakan dalam keempatempat ayat $\mathrm{BC}$ yang merangkumi ayat pertanyaan, ayat imperatif, ayat kepastian dan ayat interjektif. Sebagai contoh, Zhang Bin menyenaraikan "a" sebagai yuqi zhuci yang boleh digunakan dalam keempat-empat ayat BC tersebut tetapi yuqi zhuci "ba" pula hanya digunakan dalam ayat pertanyaan, ayat imperatif dan ayat kepastian. Dalam aspek ini, dapatan kajian ini adalah sejajar dengan pernyataan yang dikemukakan oleh Zhang Bin (2010).

Daripada sudut lain, kajian ini mendapati bahawa penterjemahan yuqi zhuci tipikal adalah rumit kerana ia bersifat tersirat dan tidak mudah untuk disalin fungsinya secara langsung. Antara faktor yang perlu diberikan perhatian adalah fungsi yuqi zhuci tipikal yang hadir dalam teks sumber, konteks cerita, niat penutur dan ketepatan nada penutur. Dengan perkataan lain, fungsi kata abstrak yuqi zhuci tipikal BC tidak dapat diterjemahkan dengan padanan leksikal dalam BM, sebaliknya diterjemahkan fungsinya melalui konteks ayat dalam BM. Tambahan pula, penguasaan konteks ayat dalam teks sasaran juga adalah penting bagi mengelakkan berlakunya salah terjemah. 
Selain itu, pengguguran yuqi zhuci tipikal dilakukan sekiranya terdapat perbezaan hukum tatabahasa. Yuqi zhuci tipikal tidak ada padanan sejadi dalam BM kerana emik BM tidak memerlukannya. Oleh itu, untuk menghasilkan terjemahan sejadi, pengguguran perlu dilakukan, dan fungsi yuzi zhuci tipikal yang terlibat dapat ditimbal balik melalui leksikal lain dalam ayat BM atau melalui konteks keseluruhan ayat tersebut dalam teks sasaran.

\section{Penghargaan}

Penulis merakamkan ucapan terima kasih kepada Universiti Sains Malaysia dan Kementerian Pendidikan Malaysia atas pemberian geran Fundamental Research Grant Scheme (FRGS; 203/PHUMANITI/6711442).

\section{Lampiran}

\section{Teks sumber}

Teks sumber merupakan cerpen-cerpen terbitan akhbar dan majalah yang diperoleh daripada penyelenggara teks sasaran dan tidak dapat dikesan maklumat penerbitannya. Berikut diturunkan nama pengarang asal dan tajuk cerpennya:

\begin{tabular}{|c|c|c|c|c|}
\hline \multirow{2}{*}{ No } & \multicolumn{2}{|c|}{ Tajuk Cerpen } & \multirow{2}{*}{ Penulis } & \multirow{2}{*}{ Penterjemah } \\
\hline & BC & $\mathbf{B M}$ & & \\
\hline 1. & $\begin{array}{l}\text { 细雨纷纷 } \\
\text { [xiyu fenfen] }\end{array}$ & Dalam Hujan Renyai & Xiao Hei & Woo Tack Lok \\
\hline 2. & $\begin{array}{l}\text { 茉莉花香 } \\
\text { [moli huaxiang] }\end{array}$ & Semerbak Melur & Shang Wanyun & Chong Fah Hing \\
\hline 3. & $\begin{array}{l}\text { 流民 } \\
\text { [liumin] }\end{array}$ & Orang Hanyut & Fan Min & Chong Fah Hing \\
\hline 4. & $\begin{array}{l}\text { 打猎 } \\
\text { [dalie] }\end{array}$ & Berburu & Mahan & Willy \\
\hline 5. & $\begin{array}{l}\text { 咸水芭事件 } \\
\text { [xian shui ba shijian] }\end{array}$ & $\begin{array}{l}\text { Kisah Perkebunan } \\
\text { Kiem Cui }\end{array}$ & Cheng Keda & Hong Seyu Luen \\
\hline 6. & $\begin{array}{l}\text { 不出卖土地的人 } \\
\text { [bu chumai tudi de ren] }\end{array}$ & $\begin{array}{l}\text { Mereka yang Enggan } \\
\text { Menjual Tanah }\end{array}$ & Yu Chuan & C.K. Goh \\
\hline 7. & $\begin{array}{l}\text { 幻 } \\
\text { [huan] }\end{array}$ & Khayalan & Zi Ling & Rozita A. Ghani \\
\hline 8. & $\begin{array}{l}\text { 过眼云烟 } \\
\text { [guoyan yunyan] }\end{array}$ & Sepintas Lalu & $\mathrm{Ai} \mathrm{Si}$ & C.K. Goh \\
\hline
\end{tabular}


(sambungan)

\begin{tabular}{|c|c|c|c|c|}
\hline \multirow{2}{*}{ No } & \multicolumn{2}{|c|}{ Tajuk Cerpen } & \multirow{2}{*}{ Penulis } & \multirow{2}{*}{ Penterjemah } \\
\hline & BC & BM & & \\
\hline 9. & $\begin{array}{l}\text { 梦魇岁月 } \\
\text { [mengyan suiyue] }\end{array}$ & Igauan Ngeri & Fang Ye & Willy \\
\hline 10. & $\begin{array}{l}\text { 安享晚年 } \\
\text { [anxiang wannian] }\end{array}$ & $\begin{array}{l}\text { Hari-Hari Menjelang } \\
\text { Tua }\end{array}$ & Ye Lei & $\mathrm{Ng}$ Hun Poh \\
\hline 11. & $\begin{array}{l}\text { 麻河的水声 } \\
\text { [mahe de shuisheng] }\end{array}$ & $\begin{array}{l}\text { Bunyi Air Sungai } \\
\text { Muar }\end{array}$ & Hong Quan & Budiria Woo \\
\hline 12. & $\begin{array}{l}\text { 小玉 } \\
\text { [xiaoyu] }\end{array}$ & Xiao Yu & Dai Xiaohua & Rozita A. Ghani \\
\hline 13. & $\begin{array}{l}\text { 浪蝶。苦花。恋 } \\
\text { [lang die. ku hua. lian] }\end{array}$ & $\begin{array}{l}\text { Buaya Darat, Bunga } \\
\text { Nasib dan Percintaan }\end{array}$ & Tang Peng & $\mathrm{Ng}$ Hun Poh \\
\hline
\end{tabular}

\section{Teks sasaran}

Lim Chuan Boon (Penyelenggara). 2000. Cerpen sastera mahua III: Dalam hujan renyai. Kuala Lumpur: Dewan Bahasa dan Pustaka. 


\section{Rujukan}

Dai Zhaoming. 2006. Cong 'ye' dao 'a' (Daripada “ye” kepada “a”). In Proceedings of the 37th International Conferences on Sino-Tibetan Languages and Linguistics (ICSTLL), vol. 12. Harbin: Heilongjiang University Press.

2008. The typological value of the Chinese modality particles. China: Research Centre for Chinese, Heilongjiang University, Harbin.

Fu You. 1997. Xiao yi yuqi zhuci 'ma' (Perbincangan yuqi zhuci 'ma'). Zhongguo Renmin Daxue Xuebao (Buletin Renmin University of China) 6: 93-95.

Goh Sang Seong. 2011. Penterjemahan kata kerja bahasa Cina-bahasa Melayu: Satu analisis ketepatan makna padanan. GEMA Online ${ }^{\circledR}$ Journal of Language Studies 11(1): 35-56.

2013. Penterjemahan nama perniagaan bahasa Cina ke dalam bahasa Melayu. Jurnal Bahasa 27: 170-185.

2014. Kaedah penterjemahan kata sendi bahasa Cina-bahasa Melayu. Procedia-Social and Behavioral Sciences 134: 246-248. https://doi.org/10.1016/j. sbspro.2014.04.245

Goh Sang Seong and Mashudi Kader. 2004. Penterjemahan kata kerja bahasa Mandarin kepada bahasa Melayu: 说 (shuo 'berkata'). Jurnal Bahasa 4(2): 225-256.

Jakobson, R. 2004. On linguistic aspects of translation. In The translation studies reader (2nd ed.), ed. L. Venuti, 138-143. London and New York: Routledge.

Jennica Chin Ai Ai and Goh Sang Seong. 2017. Kaedah penterjemahan kata abstrak 'yuqi zhuci tipikal' ke dalam bahasa Melayu. GEMA Online ${ }^{\circledR}$ Journal of Language Studies 17(3):120-136. https://doi.org/10.17576/gema-2017-1703-08

Larson, M. 1984. Meaning based translation: A guide to cross language equivalence. Boston: University Press of America.

Lau Yoke Lian. 2009. Kajian metafora kata nama dan kata sifat dalam cerpen bahasa Mandarin. Unpublished master's dissertation, Universiti Malaya.

Liu Danqing. 2003. Yuxu leixing xue yu jieci lilun (Tipologi struktur ayat dan teori kata sendi). Beijing: The Commercial Press.

Lu Jingguang. 2001. Hanyu yuqi ci leixing xue kaocha (Kajian tipologi yuqi ci dalam bahasa Cina). Hong Kong: Linguistics Department, University of Hong Kong.

Lü Shuxiang. 1982. Zhongguo wenfa yaolue (Outline of Chinese grammar). Beijing: The Commercial Press.

Ma Jianzhong. 1989. Mashi wentong (Rampaian sastera aliran ma). China: Beijing University Press.

Newmark, P. 1988. A textbook of translation. Hertfordshire: Prentice-Hall International.

Nida, E.A. and Taber, C.R. 1982. The theory and practice of translation. Leiden: E.J. Brill.

Ooi Hoey Boey. 2013. Strategi penterjemahan kata nama khas dalam teks kesusasteraan klasik negara China ke bahasa Melayu. Unpublished master's dissertation, Universiti Malaya.

Qi Huyang. 2002. Lun xiandai hanyu yuqi xitong de jianli (Pembinaan sistem yuqi dalam bahasa Cina moden). Chinese Language Learning 2: 9-20.

Shao Jingmin. 2007. Xiandai hanyu tonglun (Bahasa Cina moden). Shanghai: Education Publishing House. 
Tan Tiam Lai and Norul Haida Reduzan. 2013. Analisis kontrastif kata ganti nama diri dalam bahasa Cina dan bahasa Melayu. Pendeta: Jurnal Bahasa dan Sastera Melayu 4: 162-179.

Wang Li. 1985. Zhongguo xiandai yufa (Tatabahasa moden bahasa Cina). Beijing: Shangwu Yinshuguan.

Wu Fuxiang. 2012. Self-selected works by the well-known middle-aged linguist. Shanghai: Shanghai Education Publishing House.

Zhang Bin. 2010. Xiandai hanyu miaoxie yufa (Deskripsi tatabahasa moden bahasa Cina). Beijing: The Commercial Press. 